\title{
PROCEEDINGS OF THE FIFTY-FIRST ANNUAL MEETING
}

\author{
Jeff Swinebroad, Secretary
}

The Fifty-first Annual Meeting of the Wilson Ornithological Society was held jointly with the Cooper Ornithological Society 18-21 June, 1970, at Colorado State University, Fort Collins, Colorado. Sponsors were Colorado State University, the Colorado Field Ornithologists, the Denver Field Ornithologists, and the Fort Collins Bird Club.

The meeting started on Thursday with a welcome by Gustav A. Swanson, Colorado State University and responses by Robert T. Orr, President of the Cooper Ornithological Society and William W. H. Gunn, President of the Wilson Ornithological Society.

Paper sessions were held Thursday, Friday, and Saturday. On Friday there was a special symposium, Avian Ecology in Grasslands, arranged by John A. Wiens. Friday evening there was a joint informal banquet, a buffalo barbecue and rodeo at the TwoBar-Seven Ranch. The Colorado Field Ornithologists held a dinner meeting on Saturday.

An evening program on field trips was given Saturday evening by Clait Braun, Birds of Rocky Mountain National Park, and Ronald A. Ryder, Birds of Pawnee National Grasslands.

Three field trips were conducted on Sunday, two all day trips to the aforementioned areas, and a third trip of a half day to local areas.

The recipient of the Wilson Prize, for the best paper presented by a student or nonprofessional member of the Wilson Society, was announced at the second business meeting and was Ronald M. Case whose paper was "Bioenergetics of a Covey of Bobwhite Quail."

\section{First Business Meeting}

The first business meeting, held Friday morning, was presided over by President Gunn. The minutes of the previous meeting as included in the Proceedings of the Fiftieth Annual Meeting in the Bulletin were approved as published.

The President designated the following temporary committees:

Nominating: Phillips B. Street, Chairman, Aaron Bagg, Olin Sewall Pettingill.

Resolutions: Kenneth C. Parkes, Chairman, Roland C. Clement, W. John Richardson. Wilson Prize: Harvey I. Fisher, Chairman, Robert W. Storer, Stephen M. Russell. Auditing: C. Chandler Ross.

The Secretary reported a brief summary of the meeting of the Executive Council of the Society:

1. The Council received and approved reports of the Treasurer, the Trustee's report, the reports of the Membership, Student Membership, Library, Research Committees, and the Editor's report and the Secretary's report.

2. On recommendation of the Research Committee the Council voted to award the Fuertes Award of $\$ 200$ to Thomas C. Dunstan, South Dakota University, for his post-fledgling ecology of Great Horned Owls as determined by telemetry.

3. The Membership Committee (David F. Parmelee, Chairman) reported over 100 new members. The President appointed the First Vice President, Pershing B. Hofslund as Chairman of the Membership Committee for the coming year.

4. The Student Membership Committee canvassed a large number of professors at colleges and universities and received 143 nominations for student memberships. The Council commended Chairman Douglas James for his efforts.

5. Dr. George Hall was reelected unanimously as Editor of the Wilson Bulletin. 
6. The Council approved a new dues schedule, starting next year. The dues will be: Active $-\$ 8.00$; Sustaining $-\$ 15.00 ;$ Life $-\$ 200.00$; and Patron-\$500.00. There will be a period when Life Memberships will be available at the current level of $\$ 150.00$.

7. The 1971 meeting will be held 22-25 April on Dauphin Island, Alabama, with the Mobile County Bird Club as host.

The Treasurer summarized his report which is included here in full for the record:

\section{Report of the Treasurer for 1969}

\section{General Fund}

Balance as shown by last report 31 December 1968 $\$ 9,429.79$ RECEIPTS

Dues

Active Memberships

$\$ 3,019.44$

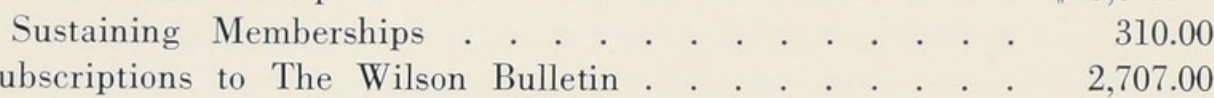

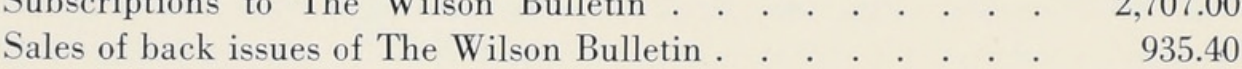

Interest and dividends on savings and investments . . . . . 2,997.57

Royalties from microfilming back issues of The Wilson Bulletin

Total Receipts . . . . . . . . . . . . . $\overline{\$ 10,080.56}$

DISBURSEMENTS

The Wilson Bulletin (Printing \& Engraving) . . . \$12,814.24

Less contributions from authors . . . . . . . 650.25

and illustration fund . . . . . . . . . . $1,000.00$

The Wilson Bulletin (Mailing \& Maintenance of List) . . . .

Editor's expense . . . . . . . . . . . . . . . .

Secretary's expense . . . . . . . . . . . . . . . .

Treasurer's expense . . . . . . . . . . . . . . .

Foreign discount, bank charge, and transfer fees . . . . . .

Annual Meeting expense . . . . . . . . . . . . .

Committee expense . . . . . . . . . . . . . . . .

Miscellaneous expense . . . . . . . . . . . . . . .

International Council for Bird Protection (1969 dues) . . . . 25.00

Transfer to Research and Award Funds . . . . . . . . . 240.00

Total Disbursements . . . . . . . . . . . \$14,188.14

Excess of Disbursements over Receipts for Year 1969 . . . . . . $\$(4,107.58)$ GENERAL FUND CASH ACCOUNTS

Checking Account . . . . . . . . . . . . . . . . . . . . $\$ 1,83699$

Savings Account . . . . . . . . . . . . . . . . . . . . . $3,485.22$

Balance in National City Bank, Cleveland, Ohio, 31 December 1969.

$\$ 5,322.21$

JOSSELYN VAN TYNE MEMORIAL LIBRARY BOOK FUND

Balance as shown by last report dated 31 December 1968 . . . . . . . . . \$ $\$ 156.75$ RECEIPTS

Sale of duplicates and gifts . . . . . . . . . . . . . . . . . 4450

Total Balance and Receipts . . . . . . . . . . . . . 161.25 


\section{DISBURSEMENTS}

Purchase of Books . . . . . . . . . . . . . . . . . . 33.10

Balance in National City Bank, Cleveland, Ohio, 31 December 1969.

Balance as shown by last report dated 31 December 1968 . . . . . . . . . . \$

RECEIPTS

Contributions . . . . . . . . . . . . . . . . . . . . . . 23650

Transfer from General Fund . . . . . . . . . . . . . . . . 24000

Total . . . . . . . . . . . 503.00

DISBURSEMENTS

Award to Richard E. Johnson . . . . . . . . . . . . \$ 200.00

Award to G. Frederick Shanholtzer . . . . . . . . . 100.00

Award to Martha Whitson . . . . . . . . . . 100.00

Total Disbursements . . . . . . . . . . . . . . . . 400.00

Balance in National City Bank, Cleveland, Ohio, 31 December 1969 . . . . $\$ \frac{\$ 103.00}{}$

PREPAID STUDENT DUES

Balance as shown by last report dated 31 December 1968 . . . . . . . . . \$ 115.00

RECEIPTS . . . . . . . . . . . . . . . . . . . . . . . 000

Total . . . . . . . . . . . . . . . . . . . 115.00

DiSBURSEMENTS . . . . . . . . . . . . . . . . . . . . . . . 10.00

Balance in National City Bank, Cleveland, Ohio, 31 December 1969 . . . . $\$ 105.00$

ENDOWMENT FUND

Balance in Endowment Fund Savings Account

as shown by last report dated 31 December 1968 . . . . . . . . . $\$ 3,607.00$ RECEIPTS

Life Membership Payments . . . . . . . . . . . $\$ 1,130.00$

Patronship Payments . . . . . . . . . . . . . . . 30000

Stock Dividends and Exchanges (included below)

$\$ 5,000$ U.S. Treas. $8 \%$ notes due 15 May 1971

received in exchange for $\$ 5,000$

U.S. Treas. $4 \%$ bonds due 10 October 1969.

135 shares Phillips Petroleum Co. received from

2 for 1 split.

33 shares Massachusetts Investors Trust

(as capital gains distribution)

Total Receipts................ . . $1,430.00$

DISBURSEMENTS

Balance in Endowment Fund Savings Account

National City Bank, Cleveland, Ohio, 31 December 1969 . . . . . \$5,037.00 SECURITIES OWNED (listed at closing prices, 31 December 1969)

United States Government bonds and notes . . . . . . . . . \$9,503.12

Canadian Provincial Government bonds . . . . . . . . 3,650.00

Corporate bonds . . . . . . . . . . . . . . . . . 3,400.00 
Convertible Corporate bonds . . . . . . . . . . . . . $3,750.00$

Convertible preferred stocks . . . . . . . . . . . . . $21,629.50$

Common stocks . . . . . . . . . . . . . . . . . $14,489.38$

Investment trusts . . . . . . . . . . . . . . . . . $8,080.08$

Total Securities Owned . . . . . . . . . . . . . . 64,502.08

Total Endowment Fund 31 December 1969 . . . . . . . . . . . . \$69,539.08

Respectfully submitted,

William A. Klamm, Treasurer

Also for the record here are summaries of the Library Committee's Report and the Editor's Report:

Library Committee (William A. Lunk, Chairman) - There was a considerable increase in the number of contributions and a slight increase in the number of loans and journals received. Four thousand one hundred reprints were a gift of Mrs. Van Tyne from the library of her late husband Josselyn Van Tyne.

Editor's Report (George A. Hall) - Volume 81 (1969) consisted of 496 pages. Papers received today should appear in 15 months. Of major importance to the Bulletin and to the Society was the retirement of Sewall Pettingill from the post as Ornithological Literature Editor. The several editors whom he has served and the Society certainly owe him many thanks for his fine efforts over the years. The new review editor is Dr. Peter Stettenheim.

\section{SECOND BUSINESS MEETING}

President Gunn presided over the second business meeting Saturday afternoon. Dr. Kenneth Parkes read the following joint Cooper-Wilson Societies resolutions:

WHEREAS the Cooper Ornithological Society and the Wilson Ornithological Society have assembled in their first joint, annual meeting at Fort Collins, Colorado, 18-21 June, 1970 , and

WHEREAS the members of the two societies have benefited greatly from the devoted efforts of the Committee on Arrangements chaired by Dr. Ronald A. Ryder, and

WHEREAS the superior facilities and services provided by Colorado State University have contributed immeasurably to the success and enjoyable nature of this meeting,

THEREFORE BE IT RESOLVED that the Cooper and Wilson Ornithological Societies extend their grateful appreciation to the sponsoring organizations: Colorado State University, The Colorado Field Ornithologists, The Denver Field Ornithologists, and The Fort Collins Bird Club.

WHEREAS the Wilson and Cooper Ornithological Societies represent an important cross section of the scientific community concerned with the study and conservation of birds in North America, and

WHEREAS the officers and members of the Wilson and Cooper Ornithological Societies share a great concern about the future biological productivity of Alaska, particularly in view of pending proposals for exploitation of Alaskan resources,

THEREFORE BE IT RESOLVED that the two societies wish, first, to commend Secretary of the Interior Walter J. Hickel for insisting on proper scientific and engineering assessment of the impact of such exploitation on the environment of Alaska, and, second, to urge that final decisions relating to Alaska be made on the basis of a national accounting rather than merely state, regional, or special interest group considerations, and 
BE IT FURTHER RESOLVED that copies of this resolution be sent to Secretary of the Interior Walter J. Hickel and to the Governor, U.S. Senators, and Representatives of the State of Alaska.

WHEREAS more species of endemic birds have become extinct in Hawaii during the past century than in the entire North American continent, and

WHEREAS at least one-third of the extant Hawaiian birds are now classified as "rare and endangered," and

WHEREAS wetland areas are essential to the survival of Hawaii's marsh and pond birds,

THEREFORE BE IT RESOLVED that the Cooper and Wilson Ornithological Societies urge that all State and Federally owned marshlands in Hawaii be declared Wildlife Refuges for these birds, and that pertinent privately owned lands be acquired and put into public ownership by the Federal or State governments or by both, and

BE IT FURTHER RESOLVED that copies of this resolution be sent to Secretary of the Interior Walter J. Hickel and to the Governor, U.S. Senators, and Representatives of the State of Hawaii.

WHEREAS the first joint meeting of the Cooper Ornithological Society and the Wilson Ornithological Society has been a notable success in providing an opportunity for intellectual and social exchange among the members of the societies,

THEREFORE BE IT RESOLVED that the officers of the societies be encouraged to take advantage of every opportunity to stage additional joint meetings of this type at suitable intervals.

Respectfully submitted,

For the Cooper Ornithological Society: Tom J. Cade, Richard F. Johnston, John Davis, Chairman.

For the Wilson Ornithological Society: W. John Richardson, Roland C. Clement, Kenneth C. Parkes, Chairman.

The resolutions were approved for both Societies without a dissenting vote by members in attendance at the meeting.

The proposed new members of the Wilson Society as posted were elected without dissenting vote and the Secretary was instructed to cast a unanimous ballot.

The Auditing Committee's report was approved without a dissenting vote. The report included the following statement: "I have examined the Receipts and Expenditure Records of the Wilson Ornithological Society for the period from May 1, 1968 to May 31, 1970. The Receipts Journal was added and the totals verified. Disbursements were verified by examination of checks and bank records. I find all totals in William A. Klamm's records to be correct. And, the balance in the National City Bank of Cleveland Checking Account to be $\$ 5,403.05$ as of May 31, 1970. Frank P. McConoughey, Accountant."

The following Nominating Committee's Report was read by Dr. George H. Lowery, Jr.: President, William W. H. Gunn; 1st Vice President, Pershing B. Hofslund; 2nd Vice President, Kenneth C. Parkes; Secretary, Jeff Swinebroad; Treasurer, William A. Klamm; Elective Member of the Council, Elden W. Martin.

The slate was elected and the Secretary was directed to cast a unanimous ballot.

PAPERS SESSIONS

Robert B. Payne, University of Michigan. Local Song Dialects and Population Size in a Parasitic Bird. 
George B. Reynard, Cornell University. Study Problems of some Caribbean Bird Songs.

Vivian Telford Anderson, The Utah State University. The Development of Selected Vocalizations in Hand-reared Black-capped Chickadees.

Daniel E. Hatch, University of Nebraska. Grouping Responses of Wild Quail to Separation Calls of the Bobwhite, Scaled Quail, and their Hybrids.

Raymond B. Goldstein, University of Nebraska. Tracheal Resonance and Vocal Acoustics of some New World Quail.

David G. Ainley, Johns Hopkins University. Comfort Behavior of Adelie, African, and Humboldt Penguins.

Sidney A. Gauthreaux, Jr., and Kenneth P. Able, University of Georgia. The Influence of Wind on the Flight Directions of Passerine Nocturnal Migrants.

William E. Southern, Northern Illinois University. Influence of Disturbances in the Earth's Magnetic Field on Orientation of Ring-billed Gulls.

Robert D. Ohmart and Robert C. Lasiewski, University of California, Davis and University of California, Los Angeles. Energetic Significance of Solar Absorption and Hypothermia in the Roadrunner.

Helmut C. Mueller, University of North Carolina. The Stimuli Eliciting Sunbathing in Birds.

Ronald M. Case, Kansas State University. Bioenergetics of a Covey of Bobwhite Quail.

Elden W. Martin, Bowling Green University. Correlation of Dietary Protein with Energy and Nitrogen Balance, and Temperature Tolerance in Tree Sparrows.

Vaughn A. Langman, University of the Pacific. The development of Radio-biotelemetry Devices for Small Passerine Birds.

Cynthia Carey, Occidental College. Comparison of Salt and Water Regulation in California Quail and Gambel's Quail.

Charles H. Trost, Idaho State University. Cardiovascular Adaptations of Horned Larks to High Altitude.

Marsha Landolt and Robert B. Payne, University of Oklahoma. Thyroid Histology in the Annual Cycle, Breeding, and Molt in Tricolored Blackbirds.

Larry C. Holcomb, Creighton University. Endogenous Factors affecting Incubation Behavior in Red-winged Blackbirds.

Nancy S. Mueller, North Carolina State University. Sexual Dichromatism in the House Sparrow.

Charles G. Sibley, Yale University. Avian Hybridization across the Great Plains.

Kendall W. Corbin, Yale University. Serum Esterase and Lactic Dehydrogenase Polymorphism in the Metallic Starling.

Andrew Ferguson, Yale University. Serum Albumin Polymorphism in Paradisaea minor, Paradisaea raggianna and their hybrids.

Walter J. Bock and John Morony, Columbia University. Relationships of the Olive W arbler, Peucedramus taeniatus.

Jerome D. Robins and Gary D. Schnell, University of Kansas and O. and S. Ecosystems IRP-IBP. Skeletal Analysis of the Ammodramus-Ammospiza Grassland Sparrow Complex: A Numerical Taxonomy Study.

Lowell Spring, Oregon College of Education. A Functional-anatomical Comparison of The Two Murres.

George A. Clark, Jr., University of Connecticut. Bilateral Asymmetry and Individuality of Integumental Patterns on Avian Feet.

Robert J. Raikow, University of California, Berkeley. The Morphology and Phylogenetic Significance of the Pelvic Girdle in Ratites. 
John Davis, Hastings Reservation, University of California. Breeding Schedule of the Rufous-collared Sparrow in Coastal Peru.

Russel P. Balda and Gary C. Bateman, Northern Arizona University. Colonial Nesting of the Piñon Jay.

Lester L. Short, American Museum of Natural History. Habits of the Red-fronted Woodpecker, Melanerpes cruentatus.

C. John Ralph and Carol A. Pearson, Point Reyes Bird Observatory. Correlations of Age, Size of Territory, Plumage, and Success in Breeding White-crowned Sparrows.

Erwin E. Klaas, Rockhurst College. Influence of Cowbird Parasitism on Nesting Success in the Eastern Phoebe.

Daniel S. McGeen, Oakland University. Cowbird Density and Cowbird-host Interactions.

Bob Stewart, Point Reyes Bird Observatory. Behavior of Wilson's Warbler.

David B. Peakall, Cornell University. Breeding Biology of the Eastern Bluebird (read by Tom J. Cade).

Symposium: Avian Ecology in Grasslands,

Chairman: John A. Wiens, Oregon State University

Introductory Remarks by Chairman.

Ronald A. Ryder, Colorado State University, Seasonal Fluctuations of Bird Populations on some Colorado Grasslands.

William J. Maher, University of Saskatchewan. Growth Rates of Ground-nesting Passerine Birds at Matador, Saskatchewan, Canada.

Paul H. Baldwin, Colorado State University. Feeding Dynamics of the Lark Bunting.

Stephen G. Martin, Oregon State University. Territorial Quality and Polygny in the Bobolink.

John L. Zimmerman, Kansas State University. Survival in the Grassland Sere: the Dickcissel's Adaptations for Opportunism.

John A. Wiens, Oregon State University. Habitat Structure and Spatial Relationships among Grassland Birds.

Arthur C. Risser, Jr., University of California, Davis. The Experimental Modification of Starling Reproductive Performance at Different Densities.

Keith A. Arnold, Texas A\&M University. Survival of Banded Great-tailed Grackles at College Station, Texas.

Vivian R. Null, California State College, Hayward. Numbers, Species Composition, and Flight Patterns of Gulls near San Francisco Bay, California.

Howard L. Cogswell, California State College, Hayward. Movements of Gulls within and among Local Populations near San Francisco Bay, California.

C. W. Comer, Kansas State Teachers College, Emporia. Winter Activities of the Slatecolored Junco on the Ross Natural History Reservation.

David A. Manuwal, University of California, Los Angeles. Ecology of Cassin's Auklet on Southeast Farallon Island.

Eugene Eisenmann, American Museum of Natural History. Recent Increase and Range Extension of the White-tailed Kite in Middle America.

Fred C. Sibley, Point Reyes Bird Observatory. Annual Nesting of the California Condor.

Roland H. Wauer, Big Bend National Park. Density and Distribution of the Colima W arbler within the Chisos Mountains, Texas.

James K. Baker, National Park Service. The Fluctuating Avifauna of Santa Barbara Island, California.

Andrew J. Berger, University of Hawaii. The Nests and Eggs of some Hawaiian Birds. 
Richard D. Porter and Stanley N. Wiemeyer, Patuxent Wildlife Research Center. Reproductive Patterns in Captive American Kestrels.

Jay H. Schnell, Tall Timbers Research Station. A Live-trapping and Recapture Technique for Red-triled Hawks.

Edmund A. Hibbard, North Dakota State University. Bird Populations of Successional Forest Habitats along the Missouri River in North Dakota.

Douglas James and Steven H. Fritts, University of Arkansas. A Multivariate Analysis of Indigo Bunting Habitat in the Southwestern Part of its Breeding Range.

Jed J. Ramsey, Lamar State College of Technology. Cattle Egrets, Bubulcus ibis, in Southeast Texas.

Gene M. Christman, University of California, Berkeley. Pathologies of Slides at Scientific Meetings.

\section{Moving Pictures.}

Harvey I. Fisher, Southern Illinois University. The Laysan Albatross on Midway.

C. B. Schaughency, Chester, New Jersey. Some Birds of Mexico.

The Frame House Gallery, Louisville, Kentucky. A Bird in the Hand-A Bird in the Bush.

ATTENDANCE

Three hundred twenty nine members and guests were registered. Forty two states, four Canadian provinces and England were represented.

From Arkansas: 3-Fayetteville, Douglas A. James; Little Rock, Henry N. Halberg, Mrs. Henry N. Halberg.

From Arizona: 4-Flagstaff, Russell P. Balda; Tucson, Stephen M. Russell, Carl Tomoff, Charles Viers.

From California: 53-Berkeley, Gene M. Christman, Jane Durham, James Hunt, Ned K. Johnson, Robert Raikow; Bolinas, T. James Lewis, Fred Sibley, Bob Stewart; Carmel Valley, John Davis; Courtland, Mrs. Arvil Parker; Davis, Robert Ohmart, Arthur Risser, Jr.; Fillmore, Sidney Peyton; Hayward, Howard L. Cogswell, Mrs. Howard L. Cogswell; Hollywood, Don Bleitz; La Jolla, Miss Grenville Hatch; La Mesa, Jean W. Cohn; Long Beach, Hal Boley, Charles T. Collins; Los Angeles, Cynthia Carey, Nicholas Collias, Elsie Collias, Ed N. Harrison, Lloyd Kiff, Martin Morton, Grace Nixon, Kenneth Stager, Jack C. Von Bloecker, Jr.; Malibu, Martine Vozan, Telford H. Work; Oakland, Mrs. Enid Austin, Vivian Null; Orinda, Tom Schulenberg; Reseda, David Manuwal, Mrs. David Manuwal; Richmond, Jack Guggoh, Mrs. Jack Guggoh; Sacramento, M. D. F. Udvardy; San Diego, Gerald Collier, Michael Evans, Marjorie Mason; San Francisco, Laurence C. Binford, Robert T. Orr, Edgar Stone; San Jose, L. R. Mewaldt, Mrs. L. R. Mewaldt, John Mewaldt; San Pedro, Shirley Wells; Santa Barbara, Waldo G. Abbott; Stockton, M. Dale Arvey; Twenty-Nine Palms, James Baker; Upland, John Mortensen.

From Colorado: 62-Aurora, Lois Webster; Berthoud, Mrs. G. T. Cummings, Christian Muller, Mrs. Daniel Muller; Boulder, Carl Bock, Mrs. G. M. Booth, William Burt, Gene Elliott, Robbie Elliott, Karlo Hadow, Louise Hering, Mrs. Dorothy A. Herman, Richard Jones, Paul Julian, Mrs. Paul Julian, Terry A. May, David Norris, Mrs. Ralph Odell, Victor Smith, Mrs. Victor Smith, Olwen Williams; Colorado Springs, Richard G. Beidleman, Mrs. Nancy Greenleaf, Mrs. Helen Thurlow; Denver, Phyliss Caswell, William Eastnian, Thompson Marsh, Mrs. Thompson Marsh, Sadie Morrison, Mary Hope Robins, Miss Tobina Storrie, Donald Thatcher, Lynn Willcockson; Englewood, Merle Barbour; Evergreen, Winston W. Brockner, Mrs. Winston W. Brockner, Donald Malick; Fort Collins, Paul H. Bald- 
win, Clait Braun, Terry Cole, Phil Creighton, N. R. French, David Lupton, Wayne Marion, Carl Marti, Meredith Morris, Richard Olendoroff, Gary Packard, Helen Ryder, Raymond Ryder, Ronald A. Ryder, Mrs. Ronald A. Ryder, Gustav A. Swanson; Grand Junction, William Davis; Greeley, Maynard Stamper; La Junta, William Anderson, Babette Cranson, Mrs. Robert Wolfe; Lakewood, William Rayall, Jr.; Longmont, Allegra Collister; Loveland, Jean Christensen, Mr. I. K. Robertson.

From Connecticut: 6-New Haven, Peter Bottjer, Kendall Corbin, Andrew Ferguson, Charles G. Sibley, Mrs. Charles G. Sibley; Storrs, George A. Clark, Jr.

From District of Columbia: 3-W ashington, Richard C. Banks, George E. Watson, Richard L. Zusi.

From Florida: 1-Tallahassee, Jay Schell.

From Georgia: 2-Athens, Kenneth P. Able, Sidney A. Gauthreaux, Jr.

From Hawaii: 1-Honolulu, Andrew J. Berger.

From Idaho: 1-Pocatello, Charles Trost.

From Illinois: 12-Blue Island, Karl Bartel; Carbondale, Harvey Fisher, Mrs. Harvey Fisher, David Hayward, Vernon Kleen, Hohn Krull; DeKalb, William Southern; Havana, Frank C. Belrose, Jr.; Lebanon, Ernest Willoughby; Macomb, Robert Beason, Edwin Franks, Mrs. Edwin Franks.

From Indiana: 3-Hanover, J. Dan Webster; Richmond, C. S. Snow, Mrs. C. S. Snow.

From Iowa: 5-Davenport, Maria Costa, Peter Peterson, Mrs. Peter Peterson; Grinnell, Helen Stewart, Mildred Stewart.

From Kansas: 6-Emporia, C. W. Comer; Hays, Charles Ely; Lawrence, Richard F Johnston, Jerome D. Robins; Manhattan, Ronald Case, John L. Zimmerman.

From Kentucky: 1-Richmond, A. L. Whitt, Jr.

From Louisiana: 4 -Baton Rouge, George H. Lowery, Mrs. George H. Lowery; Shreveport, Horace H. Jeter, S. O. Williams III.

From Maryland: 9-Baltimore, David G. Ainley, C. John Ralph; Elliott City, Eari Baysinger, Mrs. Earl Baysinger; Laurel, Richard Porter, Chandler Robbins, Mrs. Chandler Robbins, Jeff Swinebroad; Suitland, James A. Bruce.

From Massachusetts: 6-Franklin, John Minot; Littleton, James Baird, Robert Baird; Middleboro, Paul Anderson, Mrs. Paul Anderson; South Wellfleet, Wallace Bailey.

From Michigan: 6-Ann Arbor, Robert W. Storer, Nancy White; East Lansing, George Wallace, Mrs. George Wallace; Mt. Pleasant, Harold Mahan; Pontiac, Daniel S. McGeen.

From Minnesota: 11-Duluth, Joel Bronoel, Mrs. Joel Bronoel, P. B. Hofslund; I* Moille, Mrs. Violet Nagle, Mrs. Pauline Wershofen; Minneapolis, Walter Breckenridge, Mrs. Walter Breckenridge; South St. Paul, Thomas Savage, Mrs. Thomas Savage; Stillwater, John Erickson, Mrs. John Erickson.

From Missouri: 9-Columbia, W. Reid Goforth; Kansas City, Erwin Klaas, Mrs. Erwin Klaas; St. Louis, Richard A. Anderson, Mrs. Richard A. Anderson, Margaret Feigley, Mrs. Joel Massis, James Mulligan, Lilliam Nagel.

From Nebraska: 8-Chadron, Mary Blinde, Doris Gates; Lincoln, Esther Bennett, Calvin Cink, Raymond Goldstein, Daniel Hatch, Alice Prososki; Omaha, Larry Holcomb.

From New Hampshire: 1-Manchester, Mrs. Robert P. Booth.

From New Jersey: 15-Cape May Point, Ernest A. Choate; Chester, Charles Schaughency, Mrs. Charles Schaughency; Mountainside, Albert Schnitzer, Mrs. Albert Schnitzer; Newfoundland, Evamarie Townsend; Orange, Anne Wachenfeld; 
Princeton, Charlotte DuBois; Ramsey, Mrs. Eleanor Dater; Riverton, Kenneth Reynard, Mrs. Kenneth Reynard, George Reynard; Wenonah, Edward Manners, Mrs. Edward Manners; Westfield, Norman Pilling.

From New Mexico: 2-Las Cruces, Donald Caccamise, Ralph J. Raitt.

From New York: 16-Buffalo, Alice Ulrich; Ithaca, Susan M. Budd, Tom J. Cade, Mrs. Cyril Comar, Charles Leck, Carol Pearson, Olin S. Pettingill, Jr., Mrs. Olin S. Pettingill, Jr., W. John Richardson; New York City, Dean Amadon, Mrs. Dean Amadon, Walter Bock, Eugene Eisenmann, Lester L. Short; Rochester, Roland C. Clement; Waterloo, Jayson Walker.

From North Carolina: 2-Chapel Hill, Helmut C. Mueller; Raleigh, Nancy Mueller. From North Dakota: 1-Fargo, Edmund A. Hibbard.

From Ohio: 12-Bowling Green, Elden W. Martin; Burton, Robert McCullough; Chardon, Marjorie Ramisch; East Liverpool, John Laitsch, Mrs. John Laitsch; Gambier, Robert Burns; Lakewood, William A. Klamm, Mrs. William A. Klamm; Oxford, David R. Osborne; Painesville, Mrs. Robert Booth; Ravenna, Mildred Daniels, Estrilla Daniels.

From Oklahoma: 2-Norman, Marsha Landolt, Robert B. Payne.

From Oregon: 7-Ashland, John O. Sullivan; Burns, Carroll D. Littlefield; Corvallis, Stephen Martin, John Rotenberry, John A. Wiens; Forest Grove, Vaughan A. Langman; Monmouth, Lowell Spring.

From Pennsylvania: 5-Chester Springs, Phillips B. Street; Newton, Lester Thomas, Mrs. Lester Thomas; Philadelphia, C. Chandler Ross; Pittsburgh, Kenneth C. Parkes.

From Puerto Rico: 2-Palmer, Cameron B. Kepler, Mrs. Cameron B. Kepler.

From South Dakota: 3-Rapid City, L. M. Baylor, Keith Evans, Nathaniel R. Whitney.

From Tennessee: 5-Elizabethton, Lee R. Herndon, Mrs. Lee R. Herndon; Gatlinburg, Arthur Stupka, Mrs. Arthur Stupka; Maryville, Ralph J. Zaenglein.

From Texas: 6-Austin, Gary Schnell; Beaumont, Jed Ramsey; Big Bend Natl. Park, Roland Wauer; College Station, K. A. Arnold; Dallas, Cecil Kersting; Huntsville, Ralph Moldenhauer.

From Utah: 12-Brigham City, Michael Long; Logan, Vivian Telford Anderson, Dick Burr, K. L. Dixon, Martha Lester, Mike Minock, Joe Platt, June Rushing, Richard Wilson, Janet Young; Salt Lake City, William Behle, Mrs. William Behle.

From Virginia: 2-Manassas, Mrs. Roxie Laybourne; Williamsburg, Mitchell A. Byrd.

From Washington: 5-Ellensburg, F. John Erickson, Donald F. Martin, Jared Verner, Mrs. Jared Verner; Seattle, Frank Richardson.

From West Virginia: 3-Inwood, Clark Miller; Morgantown, George A. Hall, Mrs. George A. Hall.

From Wisconsin: 2-Madison, John Watson; Viroqua, Margarette Morse.

From Wyoming: 1-Laramie, Kenneth Diem.

From Alberta: 1-Calgary, M. J. Myres.

From Ontario: 3-Aurora, R. G. Brown; Newmarket, Reg E. Chandler, Mrs. Reg E. Chandler; Toronto, William W. H. Gunn.

From Quebec: 1-Montreal, David Nettleship.

From Saskatchewan: 1-Saskatoon, William Maher.

From England: 1-Manchester, John Mosher.

Also attending: Larry DeBord, Jimm Gessaman, Douglas Vogeler. 


\section{$2 \mathrm{BHL}$ Biodiversity Heritage Library}

Swinebroad, Jeff. 1970. "Proceedings of the Fifty-First Annual Meeting." The Wilson bulletin 82(3), 343-352.

View This Item Online: https://www.biodiversitylibrary.org/item/219200

Permalink: https://www.biodiversitylibrary.org/partpdf/218858

\section{Holding Institution}

Harvard University, Museum of Comparative Zoology, Ernst Mayr Library

\section{Sponsored by}

Harvard University, Museum of Comparative Zoology, Ernst Mayr Library

\section{Copyright \& Reuse}

Copyright Status: In copyright. Digitized with the permission of the rights holder.

Rights Holder: Wilson Ornithological Society

License: http://creativecommons.org/licenses/by-nc-sa/4.0/

Rights: https://biodiversitylibrary.org/permissions

This document was created from content at the Biodiversity Heritage Library, the world's largest open access digital library for biodiversity literature and archives. Visit BHL at https://www.biodiversitylibrary.org. 